\title{
Articles
}

\section{An Integrated Strategy for Grassland Easement Acquisition in the Prairie Pothole Region, USA}

\author{
Johann Walker,* Jay J. Rotella, Charles R. Loesch, Randy W. Renner, James K. Ringelman, \\ Mark S. Lindberg, Randal Dell, Kevin E. Doherty
}

\section{J. Walker, R. Dell, R.W. Renner, J.K. Ringelman}

Ducks Unlimited, Inc., Great Plains Regional Office, 2525 River Road, Bismarck, North Dakota 58503-9011

\section{J.J. Rotella}

Department of Ecology, Montana State University, Bozeman, Montana 59717-3460

\section{C.R. Loesch, K.E. Doherty}

United States Fish and Wildlife Service, 3425 Miriam Avenue, Bismarck, North Dakota 58501-7926

\section{M.S. Lindberg}

Department of Biology and Wildlife and Institute of Arctic Biology, University of Alaska Fairbanks, Fairbanks, Alaska 99775-7500

\begin{abstract}
Acquisition of perpetual grassland easements is a principal tactic used by the United States Fish and Wildlife Service (USFWS) and its partners to protect nesting habitat for migratory birds in the Prairie Pothole Region of North and South Dakota, USA. This public-private partnership resulted in the conservation of $>344,000$ ha of grassland during 1998-2012. Past easement acquisition has been targeted to landscapes with greatest expected accessibility to breeding duck pairs without active consideration of probability of conversion or cost of protection. The rising cost of easement acquisition in recent years indicates that re-evaluation and refinement of the easement acquisition strategy could help to improve programmatic outcomes. We assessed regional patterns of easement acquisition during 1998-2012, evaluated the current targeting strategy, and used a combination of publicly available and proprietary geospatial data to develop an easementtargeting Geographic Information System that integrated information about conversion probability and protection cost with current targeting criteria. Our assessment indicated that grassland protection was negatively affected by rising land prices during 1998-2012. In the $5 \mathrm{y}$ between 2008 and 2012, about 100,000 ha of grassland were protected at a cost of $\$ 83$ million (U.S. dollars). The 2008-2012 acquisitions represented 30\% of total protection during 1998-2012 but composed $47 \%$ of the total expenditure. We observed strong evidence that easements were targeted to priority landscapes both before and after formalization of the USFWS conservation strategy in 2004. We also found evidence of an opportunity to increase efficiency of future acquisitions. We identified 0.9 million ha of currently unprotected priority grassland in the region with greater than expected conversion risk and smaller than expected protection cost. We suggest that future grassland easement acquisition be refocused on this refined priority area and that an adaptive approach to future easement acquisition (including targeted acquisitions, directed monitoring, and data-based decisions) provides a logical framework for implementation of this new strategy and will facilitate continued conservation success.
\end{abstract}

Keywords: agricultural landscapes; Anatinae; conservation planning; ducks; land protection; private lands conservation Received: May 23, 2013; Accepted: August 6, 2013; Published Online Early: August 2013; Published: December 2013 Citation: Walker J, Rotella JJ, Loesch CR, Renner RW, Ringelman JK, Lindberg MS, Dell R, Doherty KE. 2013. An integrated strategy for grassland easement acquisition in the Prairie Pothole Region, USA. Journal of Fish and Wildlife Management 4(2):267-279; 31944-687X. doi: 10.3996/052013-JFWM-035

Copyright: All material appearing in the Journal of Fish and Wildlife Management is in the public domain and may be reproduced or copied without permission unless specifically noted with the copyright symbol $\odot$. Citation of the source, as given above, is requested.

The findings and conclusions in this article are those of the author(s) and do not necessarily represent the views of the U.S. Fish and Wildlife Service.

* Corresponding author: jwalker@ducks.org 


\section{Introduction}

The Prairie Pothole Region of North and South Dakota (hereafter, PPR) is a globally important region both for agriculture and migratory birds. Most land in the PPR is privately owned and used for production of small grains, row-crops, or livestock (Johnson et al. 1994; Doherty et al., in press). North and South Dakota are major producers of wheat and cattle, and recently the planted area of row crops in these states, particularly corn and soybeans, has increased (USDA 2007). For example, during 2006-2011, 271,000 ha of grassland transitioned to corn and soybeans in the Dakotas (Wright and Wimberly 2013). The native grasslands and shallow wetlands of the PPR provide continentally significant breeding habitat for populations of wetland- and grassland-dependent migratory birds (Skagen and Thompson 2001; Kushlan 2002; PPJV 2005). During 1998-2012, this region supported an average population of 7.6 million (range $=4.5 \mathrm{M}-12.5$ million) breeding ducks (Anas spp. and Aythya spp.; Zimpfer et al. 2012) at higher recorded densities than any other area on the North American continent. Grassland provides attractive and secure nesting habitat for breeding ducks (Greenwood et al. 1995; Reynolds et al. 2001; Horn et al. 2005; Stephens et al. 2005); thus, conservation of grassland in the PPR is a high priority under the North American Waterfowl Management Plan (USFWS and Canadian Wildlife Service 1986).

Purchasing perpetual easements that protect grassland from conversion to cropland, but retain land in private ownership, is currently the principal tactic used by the United States Fish and Wildlife Service (USFWS) and other conservation organizations to permanently protect nesting habitat for ducks and other wetland- and grassland-dependent migratory birds in the PPR (PPJV 2005). Although the USFWS has acquired grassland easements in the PPR since 1970, the majority (73\%) of the total protected area has been acquired since 1998. During 1998-2012, USFWS and its conservation partners spent $\$ 156.2$ million on grassland easement acquisition in the PPR (T. Fairbanks and B. Mulvaney, USFWS Region 6 Realty Program, unpublished data). Ducks Unlimited, Inc. was the major provider of private matching funds, with contributions totaling $\$ 26.9$ million or about $17 \%$ of total funding. This public-private partnership resulted in the permanent protection of $>344,000$ ha of grassland by easements acquired during 1998-2012 (T. Fairbanks and B. Mulvaney, unpublished data).

In the past, a combination of professional judgment, logistical considerations, and breeding pair information has been used to target easement acquisitions to landscapes with the greatest abundance of breeding duck pairs (USFWS 1992). This approach was further developed and formalized by USFWS in 2004 (GAO 2007). Since 2005, easements have been prioritized based on expected accessibility of grassland nesting habitat to breeding duck pairs estimated from ongoing count surveys (i.e., Four Square Mile Breeding Waterfowl Population and Production Survey; Cowardin et al. 1995; Reynolds et al. 2006) and other potential migratory bird and endangered species benefits. The objective of this approach is to direct grassland easement acquisition to landscapes with the greatest potential benefit to upland nesting ducks (Anas spp. and Aythya spp.) and to maximize the area of protected grassland in these priority landscapes.

Recent assessments of grassland easement objectives indicate that if projected trends in grassland loss and protection cost continue, current acreage goals for grassland protection in the PPR will not be achieved (GAO 2007; Doherty et al., in press). During 1998-2012, average inflation-adjusted corn prices in North and South Dakota increased $210 \%$ (from $\$ 1.89 /$ bushel to $\$ 5.88$ / bushel) while average inflation-adjusted cropland rental rate in the PPR increased 61\% (from \$109/acre to $\$ 175$ / acre; USDA, National Agricultural Statistics Service 2012). Concurrently, the average inflation-adjusted cost of grassland easements increased 300\% from \$195/acre in 1998 to $\$ 778 /$ acre in 2012 . Conversion of grassland to cropland has also increased as the market price of profitable commodity crops such as corn has increased (Stubbs 2007; Stephens et al. 2008; Rashford et al. 2011; Wright and Wimberly 2013).

Increased commodity prices, increased cropland value, and rapid cropland expansion in the PPR indicate a need to adapt the current prioritization strategy for grassland easement acquisition in response to increased protection cost. Additional need for refined targeting is evident in the rising demand for easements from private landowners, which consistently exceeds available funding (B. Mulvaney, personal communication). Because conversion probability and protection cost are spatially variable (Rashford et al. 2011; Walker 2011), incorporating information about these factors may help focus grassland easement acquisition to sites with greatest value for breeding ducks and greater risk of loss relative to protection cost and thereby lead to more cost-effective use of limited funding (Newburn et al. 2005; Pressey et al. 2007; Bode et al. 2008; Polasky 2008).

We investigated grassland easement acquisition by USFWS and its conservation partners in the PPR during 1998-2012 with three primary objectives: 1) assess the effect of rising protection costs on grassland easement acquisition at the regional level; 2) evaluate whether formalization of targeting strategy based on 2004 changed the spatial distribution of acquisitions; and 3 ) develop a new, spatially explicit easement-targeting Geographic Information System (GIS) to facilitate more strategic easement acquisition by augmenting the existing GIS-based system with information about probability of grassland conversion and cost of protection.

\section{Methods}

\section{Analysis area}

The analysis area comprised the Prairie Pothole Region of North and South Dakota (Figure 1). The climate, land use, and physical geography of this region are welldescribed elsewhere (e.g., Bluemle 1991; Johnson et al. 1994; Millett et al. 2009). Because of the PPR's importance to breeding ducks and other grassland birds, this area is the focus of easement acquisition efforts and 


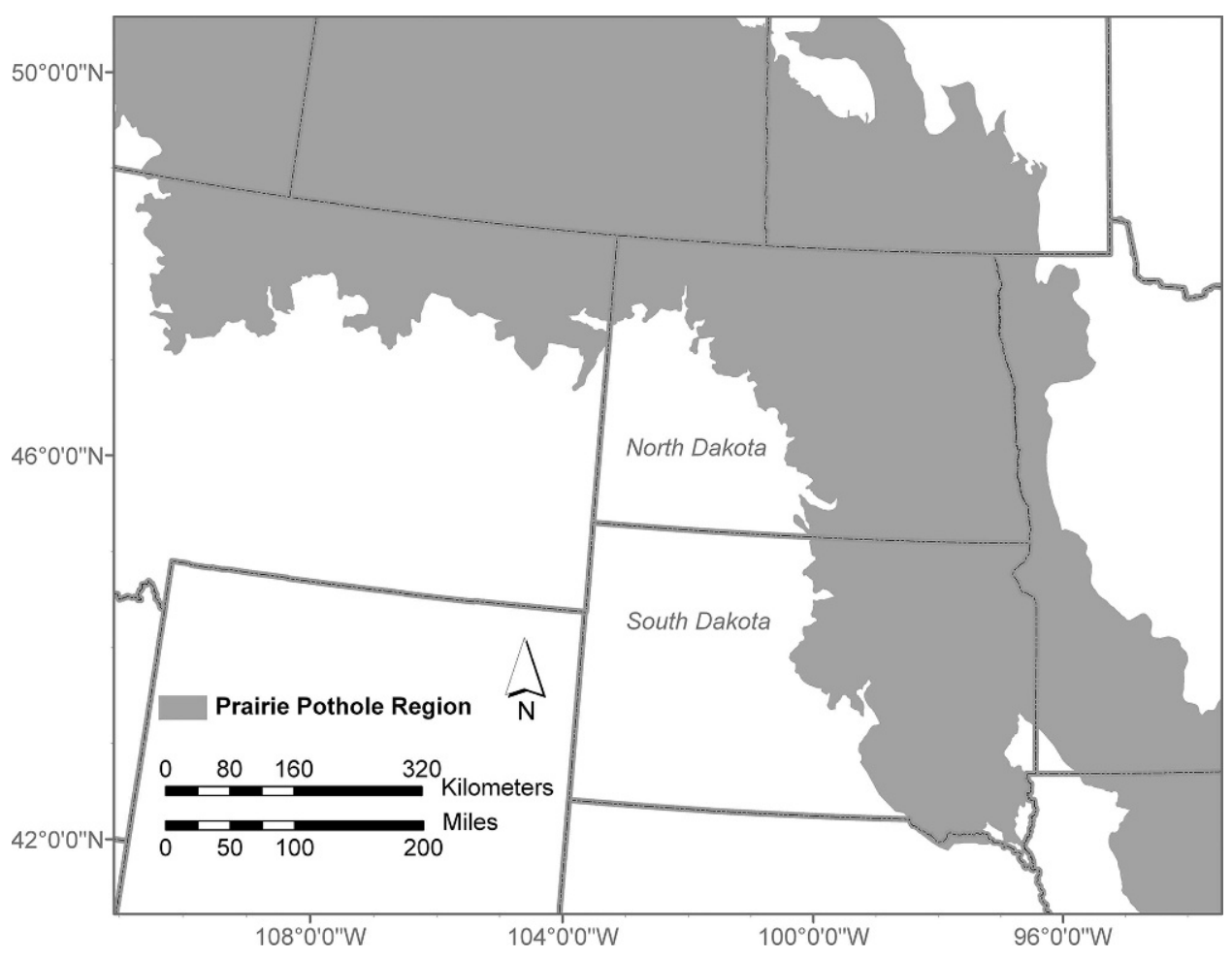

Figure 1. Location and extent of the Prairie Pothole Region in North and South Dakota.

accounts for $80 \%$ (0.9 million ha) of the total area of all types of easements held by USFWS nationwide (USFWS 2011). We separated North and South Dakota in all comparative analyses, because easement programs in the two states are delivered by different personnel and are subject to different state-level administrative constraints.

\section{Assessment of recent easement acquisitions}

We assessed temporal patterns in region-wide grassland easement acquisition in North and South Dakota during 1998-2012 with data from the USFWS Region 6 Realty Program (T. Fairbanks and B. Mulvaney, unpublished data). Specifically, we used the $R$ environment ( $R$ 2.15.1; R Development Core Team 2012) and the contributed package ggplot2 (Wickham 2009) to examine the total number of U.S. dollars spent (in 2005 dollars), the total area protected, and the unit cost of grassland protection (in 2005 dollars per hectare) by year for each state. We looked for patterns in the year-to-year data consistent with recent trends in commodity prices and cropland rental rate, including increased overall cost, decreased area protected, and increased protection cost per unit area.

\section{Evaluation of current targeting strategy}

We investigated whether the easement acquisition strategy developed by USFWS in 2004 and subsequently adopted by the Prairie Pothole Joint Venture (joint ventures are partnerships established under the North American Waterfowl Management Plan to help conserve the continent's waterfowl populations and habitats) changed targeting of easements to priority landscapes after it was implemented in 2005. We used publicly available and proprietary geospatial data (Table 1; publicly available data in Data S1, proprietary USFWS grassland easement data available by special request from the current Project Leader, USFWS Region 6 HAPET, Bismarck, North Dakota) and standard tools in ArcGIS Desktop 10.0 (ESRI, Inc., Redlands, California) to compare the spatial distribution of grassland protected during 1998-2004 (preconservation strategy) with the spatial distribution of grassland protected during 2005-2012 (postconservation strategy). To avoid errors when calculating areas, all spatial analyses were conducted in the same map projection and datum (Universal Transverse Mercator Zone 14 North, North American Datum 1983). We ran the repair geometry tool on all feature class layers before converting to grid data. We used the snap raster tool to align all grid layers to a common grid with the same extent as the analysis area.

We characterized the spatial distribution of grassland easements in terms of current priorities by combining the USFWS grassland easement layer with the 3-class layer of USFWS acquisition priority based on accessibility to breeding duck pairs (Pairs Class 1 comprises areas accessible to $\geq 23$ pairs $/ \mathrm{km}^{2}$ on average, Pairs Class 2 comprises areas accessible to $16-22$ pairs $/ \mathrm{km}^{2}$, and Pairs Class 3 comprises areas accessible to $10-15$ pairs $/ \mathrm{km}^{2}$ ). These priority classes encompass the spatial distribution of uplands accessible to $94 \%$ of the expected breeding duck pairs in the PPR $(4,343,248$ pairs). Specifically, we converted the USFWS priority layer to a $30-\mathrm{m}$ grid and used the Zonal Statistics tool in ArcGIS to calculate the 
Table 1. Description of geospatial data sources used to test hypotheses about spatial distribution of grassland easements acquired during 1998-2012 and create a GIS-based targeting system for grassland easement acquisitions in the United States. NA = not available.

\begin{tabular}{|c|c|c|c|}
\hline Layer name & Type & Resolution & Data source \\
\hline North and South Dakota PPR ${ }^{a}$ & Polygon feature class & NA & United States Census Bureau \\
\hline North and South Dakota PPR counties & Polygon feature class & NA & United States Census Bureau \\
\hline Priority classes for $\mathrm{FWS}^{\mathrm{b}}$ easement acquisition & Polygon feature class & NA & FWS Region 6 HAPET $^{c}$ Four Square Mile Survey \\
\hline Grassland Bird Conservation Area cores & Raster grid & $30 \mathrm{~m}$ & FWS Partners in Flight \\
\hline Grassland easements & Polygon feature class & NA & FWS Region 6 Realty Program \\
\hline Grassland cover & Raster Grid & $30 \mathrm{~m}$ & Landsat Thematic Mapper satellite imagery (2000-2003) \\
\hline Land Capability Class & Raster Grid & $30 \mathrm{~m}$ & USDA $^{\mathrm{d}}, \mathrm{NRCS}^{\mathrm{e}}$ \\
\hline Average cropland rental rate $2010-2012$ & Raster grid & $30 \mathrm{~m}$ & USDA, NASS ${ }^{f}$ cropland rental rate survey data \\
\hline
\end{tabular}

${ }^{\text {a }}$ Prairie Pothole Region.

b United States Fish and Wildlife Service.

c Habitat and Population Evaluation Team.

d United States Department of Agriculture.

e Natural Resources Conservation Service.

${ }^{f}$ National Agricultural Statistics Service.

majority (dominant) priority class associated with each grassland easement tract.

After we calculated the dominant priority class associated with existing grassland easements acquired during 1998-2012, we used a chi-squared goodness-offit test (Sokal and Rolf 1995) to statistically compare the spatial distribution of protected grasslands before and after implementation of the USFWS conservation strategy in 2005 (Fisher and Dills 2012). The null hypothesis predicted no change in the distribution of grassland easements relative to the priority classes in the period before (pre-2005) and after (post-2004) the implementation of the formal conservation strategy. We considered chi-squared statistics that had a probability of $\leq 0.05$ under the null hypothesis of identical distributions to be statistically significant, and we conducted all statistical tests in the R environment ( $R$ 2.15.1; R Development Core Team 2012). We predicted that ongoing targeting of grassland easement acquisition to areas with greater breeding pair abundance had concentrated easements in the higher ranking priority classes throughout the life of the program (USFWS 1992) and that formalization of the conservation strategy in 2004 would be associated with an increase in the number of easements acquired in higher ranking priority classes.

\section{Development of the integrated easement-prioritization GIS}

To facilitate refined targeting of easement acquisition, we combined the existing USFWS easement priority classes based on habitat value for breeding duck pairs with information about spatial variation in correlates of conversion probability and protection cost. We were particularly interested in identification of unprotected grasslands in USFWS priority class 1 or 2 (areas accessible to $\geq 16$ breeding duck pairs $/ \mathrm{km}^{2}$ ) with greater expected probability of conversion and reduced expected cost of protection relative to the remaining unprotected grassland in the priority area. We used ArcGIS to combine the existing USFWS priority layer based on spatial variation in accessibility of grassland to breeding ducks with two additional layers describing spatial variation in probability of conversion and cost of protection (Table 1; data available in Data S1). To avoid errors when calculating areas, all spatial analyses were conducted in the same map projection (Universal Transverse Mercator Zone 14 North, North American Datum 1983). We ran the repair geometry tool on all feature class layers before converting to grid data. We used the snap raster tool to align all grid layers to a common grid with the same extent as the analysis area.

Conversion probability of grassland in the analysis area is related to Land Capability Class (LCC): an index of suitability for cropping (Stephens et al. 2008; Rashford et al. 2011). Land Capability Class is an ordinal variable that ranges from 1 to 8 and increases with increasing limitations to cultivation (NRCS 1995). As a broad-scale index to conversion probability, we used LCC data from the USDA Soil Survey Geographic database (NRCS 1995). We combined the eight LCC values from the Soil Survey Geographic database (table physical name: muaggatt, column physical name: niccdcd [nonirrigated capability class]) into 3 risk classes (Risk Class $1=$ LCC values 1 and 2, Risk Class $2=$ LCC values 3 and 4, and Risk Class $3=$ LCC 5-8). We based our three classes on the results of Rashford et al. (2011), who found that conversion probability averaged $0.95 \% / y$ in our analysis area, and these classes were associated with a 3-fold (Risk Class 3 to Risk Class 2) and 1.5-fold (Risk Class 2 to Risk Class 1) increase in annual conversion probability, respectively.

We used producer-reported average county-level cropland rental rates for 2010-2012 (USDA, National Agricultural Statistics Service 2012) as an index to variation in easement cost. These rental rates are correlated $(r=0.97)$ with per hectare cost of easements across the study area (Walker 2011). We used the Interpolation tool in ArcGIS with average county-specific cropland rental rate during 2010-2012 assigned to the geographic centroid of the outer extent of each county to calculate a continuous surface of inverse-distance- 


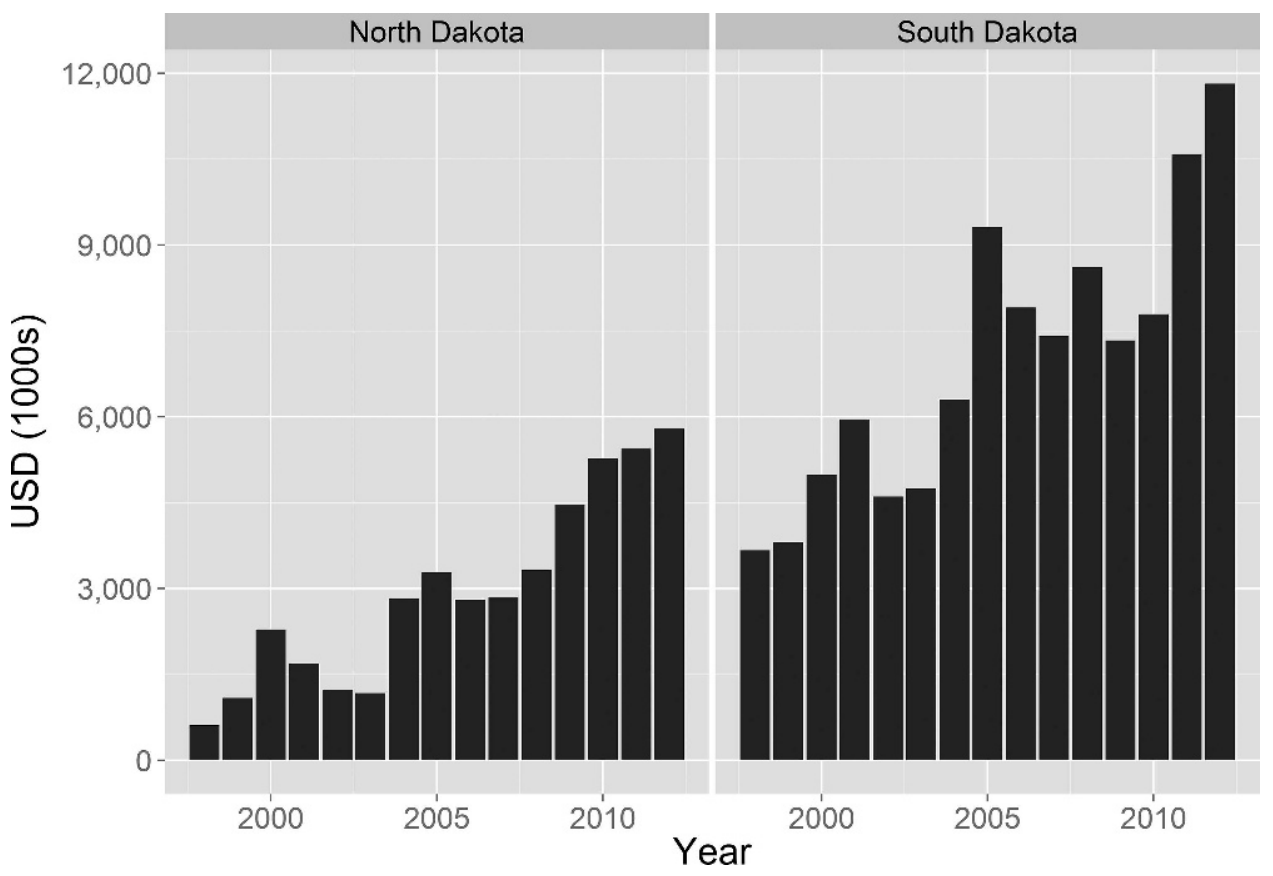

Figure 2. Annual expenditure (2005 U.S. Dollars [USD]) of the FWS perpetual grassland easement acquisition program in the Prairie Pothole Region of North and South Dakota, 1998-2012.

weighted county-level cropland rental rates. We then combined the resulting 30-m grid into a 3-class protectioncost index layer based on the empirical quantiles of the observed cropland rental-rate distribution across the analysis area during 2010-2012 (Cost Class 1 = lowest one-third of rental rate, Cost Class $2=$ middle one-third, and Cost Class 3 = top one-third).

To develop a single layer for targeting easement acquisition, we combined the USFWS priority layer based on accessibility to breeding pairs, the grassland conversion risk layer based on LCC, and the protectioncost layer based on cropland rental rate. First, we used the Map Algebra tool to sum the pairs, risk, and cost layers. Then, to adjust the resulting summed layer to the remaining unprotected grassland in the analysis area, we multiplied it by a binary land-cover grid (1 = unprotected grassland as of 2012 associated with 22 hectare) Grassland Bird Conservation Area Cores [Johnson et al. 2010], 0 = other land-cover classes). The result was a $30-\mathrm{m}$ grid describing remaining unprotected priority grassland on a summed scale from 3 to 9. Unprotected grassland with a summed value of 3 was therefore associated with $\geq 23$ breeding duck pairs $/ \mathrm{km}^{2}$, LCC rated 1 or 2, and cropland rental rate in the lowest one-third of the distribution (i.e., Pairs Class value $=1$, Risk Class value $=1$, and Cost Class value $=1$ ). Unprotected grassland with a summed value of 9 was associated with $\leq 15$ breeding duck pairs $/ \mathrm{km}^{2}$, LCC rated $5,6,7$, or 8 , and in the top one-third of the cropland rental rate distribution. We then recombined the seven grid sum values and created three integrated priority classes. Priority 1 included grid values 3 and 4, Priority 2 included grid values 5 and 6 , and Priority 3 included grid values 7, 8, and 9. Priority 1 consisted of unprotected grasslands that fell below grid value 1 on no more than one criterion, Priority 2 consisted of unprotected grasslands that fell below grid value 1 on no more than two criteria, and Priority 3 consisted of unprotected grasslands that fell below grid value 1 on at least two criteria. This prioritization was based on two ideas. First, we thought a relatively simple structure would result in a more readily implemented conservation strategy (Knight et al. 2008). Second, and more importantly, this structure focused on unprotected grassland within the existing highest priority area with likely greatest probability of conversion and lowest cost of protection, which was our primary interest.

\section{Results}

\section{Assessment of recent easement acquisitions}

During 1998-2012, USFWS and its conservation partners spent $\$ 149.0$ million (all amounts adjusted to constant Gross Domestic Product deflated 2005 U.S. dollars) on grassland easement acquisition in the PPR. More than 344,000 ha of grassland were protected at an average cost of $\$ 432 /$ ha. Most of those funds $(\$ 104.9$ million) were spent to protect grassland (191,000 ha) in South Dakota. Average unit costs of grassland protection were \$549/ha in South Dakota and \$287/ha in North Dakota. Despite a substantial increase in expenditure during the study period, there was little realized gain in the annual rate of protection. Funds expended on grassland easement acquisition increased 3-fold in South Dakota from \$3.7 million in 1998 to $\$ 11.8$ million in 2012 and 9.7-fold in North Dakota from \$0.6 million in 1998 to $\$ 5.8$ million in 2012 (Figure 2). Area protected in South Dakota ranged from 7,100 ha in 2010 to 19,300 ha in 2000 and averaged 12,750 ha/yr during 1998-2012. Area 


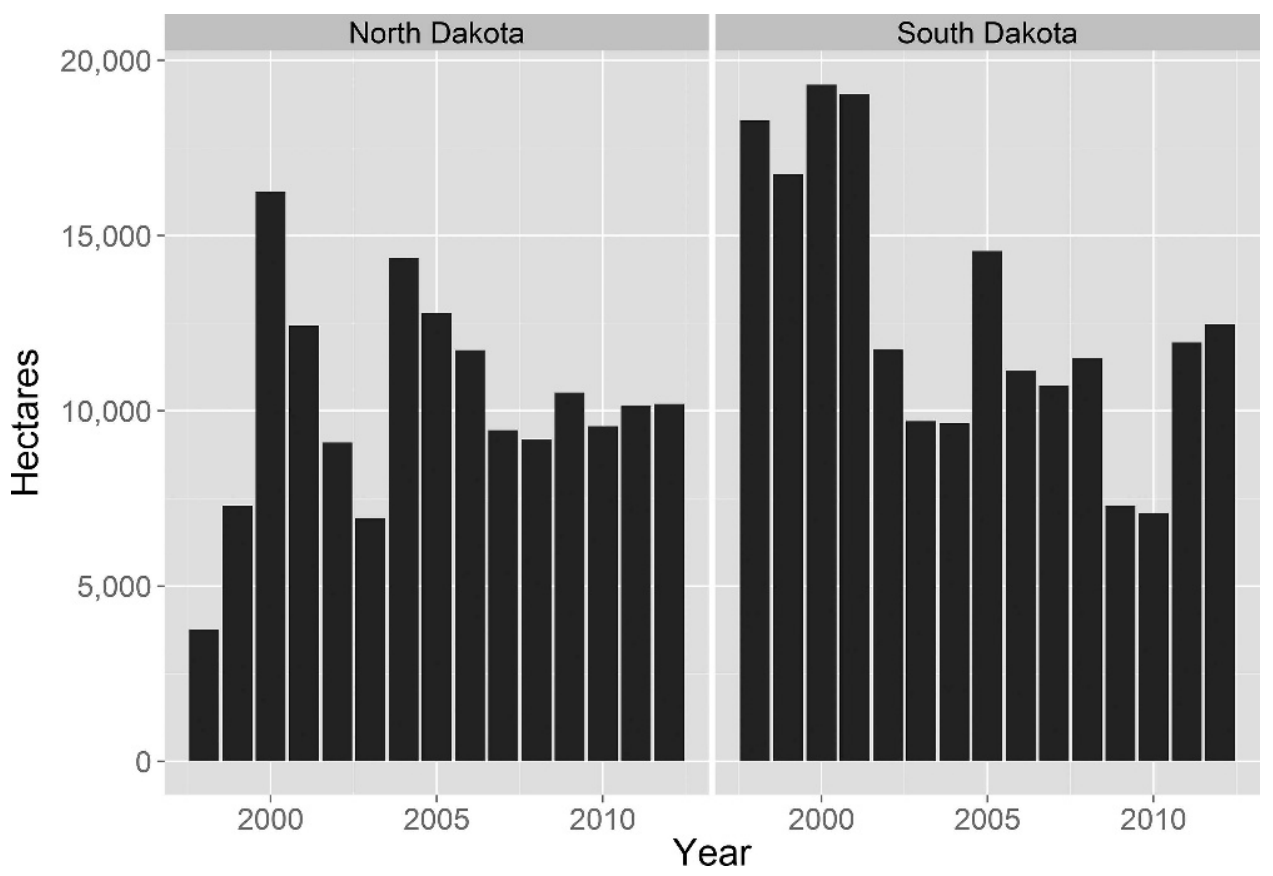

Figure 3. Area (ha) of perpetual grassland easements acquired by the U.S. Fish and Wildlife Service to prevent conversion of grassland bird nesting habitat to cropland during 1998-2012 in the Prairie Pothole Region of North and South Dakota.

protected in North Dakota ranged from 3,800 ha in 1998 to 16,300 ha in 2000 and averaged $10,300 \mathrm{ha} / \mathrm{yr}$ during 1998-2012 (Figure 3). In South Dakota, average unit cost of protection ranged from $\$ 201 /$ ha in 1998 to $\$ 1,103 /$ ha in 2010. In North Dakota, average unit cost of protection ranged from \$136/ha in 2002 to $\$ 568 /$ ha in 2012 (Figure 4).

\section{Evaluation of current targeting strategy}

We rejected the null hypothesis that easements were identically distributed among USFWS priority classes before and after the 2005 implementation of the USFWS conservation strategy. The observed distribution of easements relative to the distribution of unprotected grassland in USFWS priority classes differed from

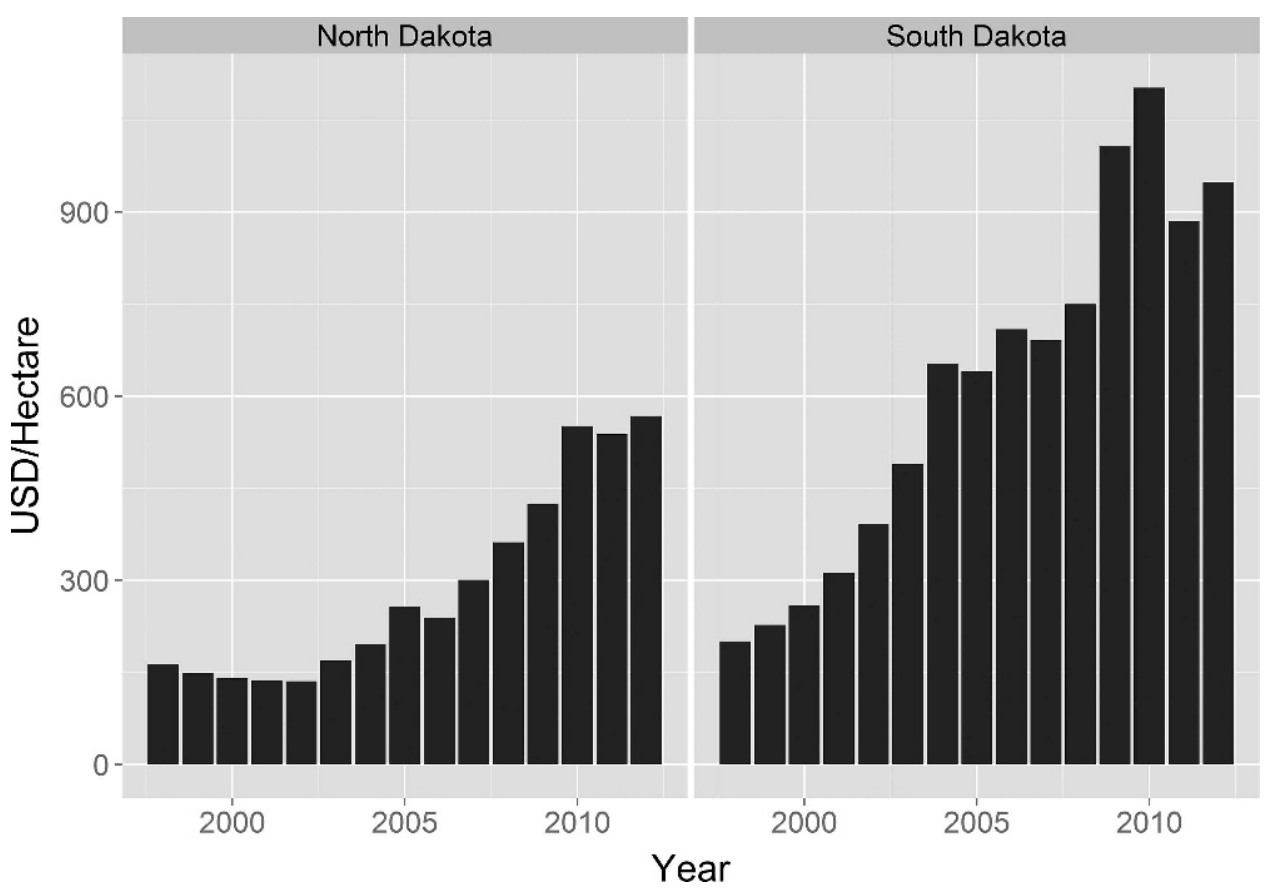

Figure 4. Unit cost (2005 U.S. Dollars [USD]/ha) of perpetual grassland easements acquired by the U.S. Fish and Wildlife Service to prevent conversion of grassland bird nesting habitat to cropland in the Prairie Pothole Region of North and South Dakota, 19982012. 

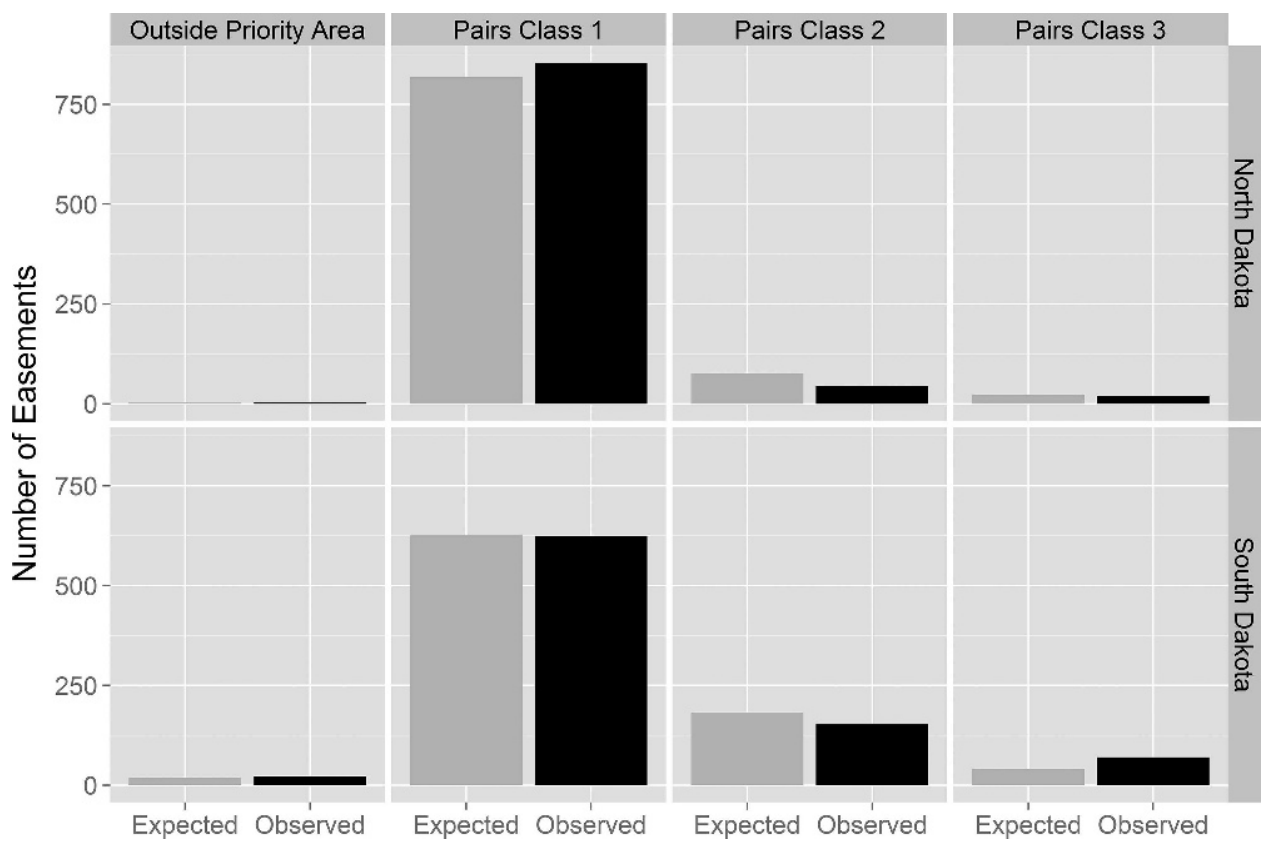

Figure 5. Expected and observed distribution of perpetual grassland easements acquired by the U.S. Fish and Wildlife Service to prevent conversion of grassland bird nesting habitat to cropland in the Prairie Pothole Region of North and South Dakota among priority classes based on expected accessibility to breeding duck pairs. Expected distribution corresponds to the distribution of easements acquired prior to the implementation of a formal conservation strategy in 2005. Observed distribution corresponds to the distribution of easements acquired after the implementation of a formal conservation strategy in 2005.

expectations in both South $\left(\chi_{3}^{2}=17.67, P=0.0005\right)$ and North $\left(\chi_{3}^{2}=25.61, P<10^{-4}\right)$ Dakota. Counter to our prediction, these results, although statistically significant, did not provide material evidence of practically significant changes associated with implementation of the conservation strategy (Figure 5). There were 3,032 and 792 easements purchased in South and North Dakota, respectively, before the implementation of the conservation strategy. In South Dakota, $72 \%$ of easements were expected in Pairs Class 1 landscapes based on observed locations of easements acquired before the implementation of the conservation strategy, and $72 \%$ of the 868 easements acquired after 2004 were in Pairs Class 1 landscapes. In North Dakota, 89\% of easements were expected in Pairs Class 1 landscapes based on observed locations of easements acquired before the implementation of the conservation strategy, and $93 \%$ of the 920 easements acquired after 2004 were in Pairs Class 1 landscapes.

\section{Development of the integrated easement-prioritization GIS}

There were 3.2 million ha of unprotected grasslands in the analysis area located in priority landscapes accessible to $\geq 10$ duck pairs $/ \mathrm{km}^{2}$. Unprotected grassland was distributed unevenly among USFWS Pairs Classes, with 1.8 million ha $(56 \%)$ in Pairs Class 1, 0.8 million ha $(25 \%)$ in Pairs Class 2, and 0.6 million ha (19\%) in Pairs Class 3. Among conversion classes within priority landscapes, we observed 1.0 million ha (32\%) of unprotected grassland in Risk Class 1, 1.2 million ha (39\%) in Risk Class 2 and 0.9 million ha (29\%) in Risk Class 3. Among Cost Classes, there were 1.4 million ha (44\%) of unprotected priority grassland in Cost Class 1 (cropland rental rate from \$72/ ha to $\$ 124 / \mathrm{ha}), 1.3$ million ha $(40 \%)$ in Cost Class 2 (cropland rental rate from $\$ 125 /$ ha to $\$ 216 / \mathrm{ha}$ ), and 0.5 million ha (16\%) in Cost Class 3 (cropland rental rate from $\$ 217 /$ ha to $\$ 400 / \mathrm{ha}$ ). When current USFWS Pairs Classes were combined with the new Risk Classes and Cost Classes, there were 0.9 million ha of Priority $1,1.7$ million ha of Priority 2, and 0.6 million ha of Priority 3 unprotected grasslands in the analysis area (Figure 6). Most of the Priority 1 and Priority 2 unprotected grassland was located in central and northwest North Dakota with a band of Priority 1 and Priority 2 grassland in the westernmost portion of the analysis area in South Dakota (Figure 7).

\section{Discussion}

Recent assessments of regional habitat protection rates indicate regional goals for grassland easement acquisition (PPJV 2005) will not be achieved given current grassland loss rates and increasing protection costs (GAO 2007; Doherty et al., in press). Our analyses of recent grassland protection activity in the PPR corroborated these results. Largely due to increasing unit cost of protection, the annualized rate of grassland protection in the PPR did not increase during 1998-2012. The effect of diminishing buying power in an appreciating land market was most apparent in recent years. In the $5 \mathrm{y}$ between 2008 and 2012, about 100,000 ha were protected at a cost of $\$ 83$ million. This acquisition represented $30 \%$ of the total area protected during 1998-2012 but $47 \%$ of total expenditure. Increases in 


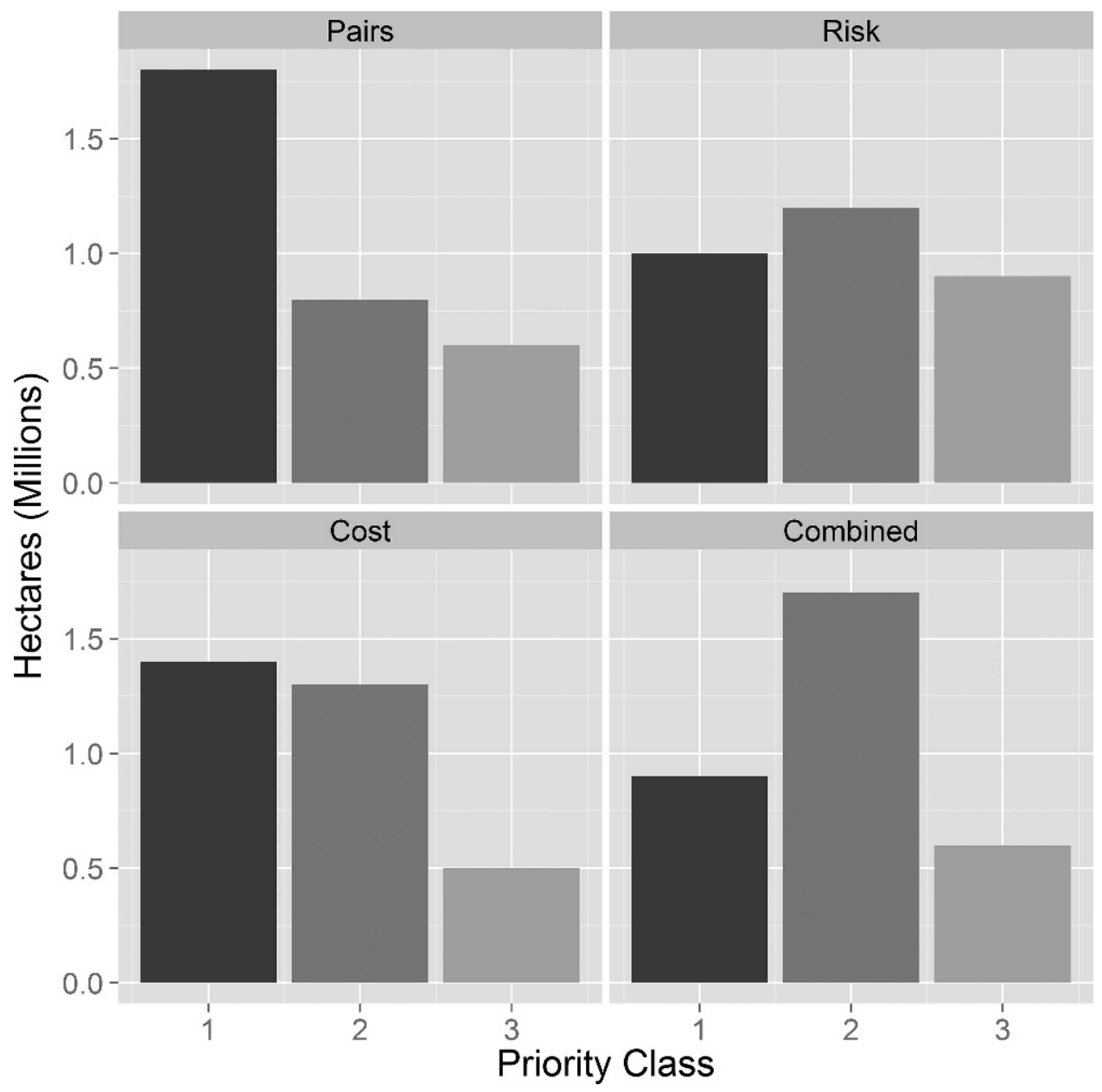

Figure 6. Area of remaining unprotected grassland in the Prairie Pothole Region of North and South Dakota by priority classes (1 $=$ highest priority, 2 = high priority, 3 = lower priority) corresponding to variation in expected abundance of breeding duck pairs (Pairs), risk of conversion (Risk), cost of protection (Cost), and Pairs, Risk, and Cost combined (Combined).

funding to the easement program have only kept pace with increasing land values and, as a result, the annual rate of protection has not increased. For example, in $1998,22,000$ ha were protected for $\$ 5.3$ million, and in $2012,22,000$ ha were protected for $\$ 20.8$ million. The $14 \%$ average year-over-year increase in easement expenditure only matches recent increases in protection cost, mandating cost-efficient targeting of resources to unprotected grasslands. Given a continued trend of increasing cropland value in the PPR, we suspect a larger area of at-risk priority grassland will ultimately be protected if conversion risk and protection cost are formally integrated into the conservation strategy (Newburn et al. 2005; GAO 2007).

At the parcel-level, grassland easements acquired during 1998-2012 were effectively targeted to the highest priority landscapes in terms of the current conservation strategy, and formalization of the conservation strategy in 2004 did not change the pattern of targeting. Over $95 \%$ of the grassland easements acquired during 1998-2012 were located in landscapes associated with the greatest expected accessibility to breeding duck pairs. This result has two implications. First, parcel-level prioritization decisions made by field personnel over the $15-y$ analysis period were compatible with the regional targeting strategy implemented by USFWS in 2004. Second, our analysis provided evidence that regionalscale prioritization schemes and local-scale, parcelspecific acquisition decisions can be coherent. Thus, efforts to add information about conversion risk and protection cost to the current targeting strategy have the potential for successful cross-scale implementation.

Implementation of easement-prioritization GIS will be most effective when parcel-level protection decisions are made in the context of the local knowledge base. The statistical relationships that formed the basis for our GIS do not predict parcel-level characteristics with certainty. Rather, they describe expected long-term, broad-scale outcomes. For example, at the regional and programmatic level, our GIS can direct easement acquisition to landscapes with greater expected abundance of breeding pairs, greater expected risk of conversion, and smaller expected cost of protection. It can also facilitate avoidance of areas with greater expected breeding-pair abundance but smaller expected conversion risk or greater protection cost. Therefore, as an initial step, the 


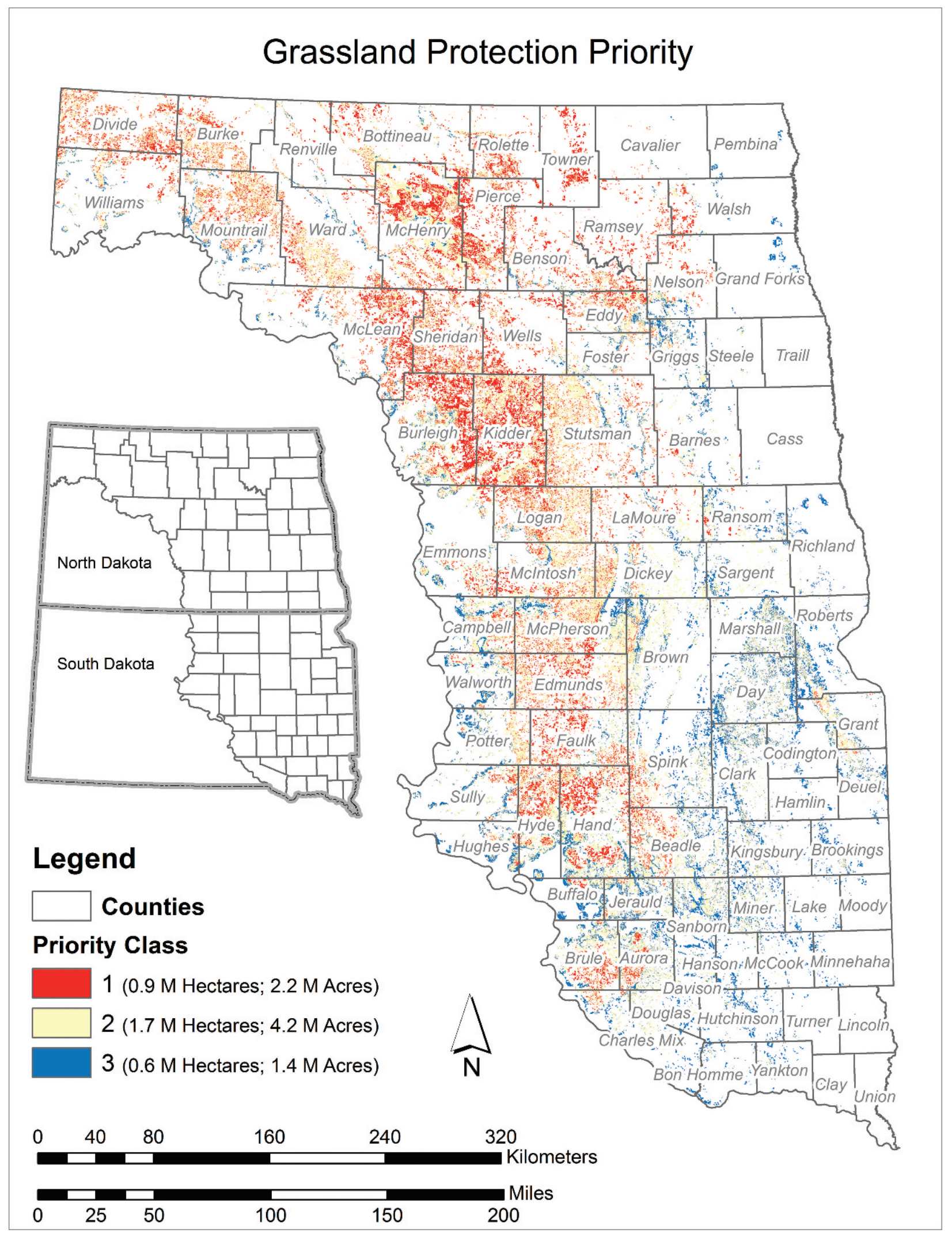

Figure 7. Location and extent of remaining unprotected grassland (in million [M] of hectares) in the Prairie Pothole Region of North and South Dakota by priority classes corresponding to variation in expected abundance of breeding duck pairs, risk of conversion, and cost of protection. 
easement-prioritization GIS could be used by field personnel to provide a ranking of competing opportunities. Then, local knowledge could be applied by field personnel to improve the initial rankings. For example, if field personnel know a local landowner who plans to convert a parcel that has relatively small expected conversion probability or a relatively costly parcel is offered in a bargain sale or as a partial donation, then those parcels should be given additional priority. Nonetheless, when parcel-specific knowledge is lacking, acquisitions made using the rankings provided by our easement-prioritization GIS are likely to balance costs and benefits in terms of the potential benefits lost per unit cost more effectively than would a strategy based strictly on breeding pair abundance.

Global change in economics, demographics, and climate is predicted to increase worldwide demand for food and energy, while increasing the uncertainty of supply (Ramankutty et al. 2008; Searchinger et al. 2008; Cirera and Masset 2010). As a result, expansion of cultivated land (Wright and Wimberly 2013) onto former grasslands is likely to continue in the PPR. Integrated targeting of easement acquisitions can help to counter this force by directing grassland protection efforts to at-risk areas with a larger benefit-cost ratio. Our assessment indicated there were 3.3 million ha of unprotected grasslands in the priority areas defined by the current targeting strategy based on abundance of breeding duck pairs. This area was nearly 10 times larger than the 344,000 ha protected during 19982012. We suggest that future grassland easement acquisitions would likely be more cost-efficient if efforts were refocused on the 0.9-million-ha highestpriority unprotected grasslands identified by our analysis. Targeting of grassland easement acquisition to a smaller area with greater expected probability of conversion and smaller expected cost of protection could provide needed support to easement acquisition efforts during a time when purchasing power is being diminished by rising land prices. For example, this approach could help to both maximize the effect of limited funding and buy time for efforts to affect landuse policies that promote grassland conservation (Carriazo et al. 2009).

Renewed focus on the strategic foundation of the grassland easement program could help to mitigate the negative effects of increasing protection cost and conversion rate. Our work to develop an integrated targeting system addresses some potential deficiencies of the acquisition strategy, but in many respects our targeting utility represents a working hypothesis supported by data and past studies. In keeping with the principles of Strategic Habitat Conservation (i.e., the current USFWS adaptive habitat-conservation paradigm based on iterative planning, implementation, and evaluation; USFWS 2008), we suggest that implementation of an integrated strategy could proceed as part of an adaptive framework for easement acquisition guided by directed monitoring and evaluation. By testing critical assumptions on a periodic basis, an adaptive approach provides needed structure for evaluating progress toward near-term programmatic objectives and for making strategic adjustments (Rissman et al. 2007; Conroy and Peterson 2009). For example, our proposed targeting strategy is focused on protection of tracts with greater than average values of breeding pair abundance and conversion probability and smaller than average values of protection cost. These assumptions could be periodically evaluated by comparing the characteristics of acquired easements with data generated by monitoring 1) distribution and abundance of breeding ducks, 2) conversion of grassland to cropland, and 3) cost of protection across the analysis area. The resulting comparison of observation with predictions would provide the objective basis for adapting easementacquisition efforts to the current ecological, economic, and political environment. By continually testing key assumptions and incorporating new information, this approach would help ensure continued success of the grassland easement program in the changing environment of the PPR.

\section{Supplemental Material}

Please note: The Journal of Fish and Wildlife Management is not responsible for the content or functionality of any supplemental material. Queries should be directed to the corresponding author for the article.

Data S1. Publicly available geospatial and tabular data for analysis of easement acquisition in the PPR of North and South Dakota is contained in the zip folder titled PPR_Easement_Acquisition

Found at DOI: http://dx/doi.org/10.3996/052013JFWM-035.S1 (47.4 MB ZIP).

Reference S1. Carriazo F, Claassen R, Cooper J. 2009. Crop insurance, disaster payments, and incentives for land use change in agriculture: a preliminary assessment. American Agricultural Economics Association, Milwaukee, Wisconsin.

Found at DOI: http://dx/doi.org/10.3996/052013JFWM-035.S2; also available at http://ageconsearch. umn.edu/bitstream/49218/2/Carriazo_AAEA09_April27.pdf (142 KB PDF)

Reference S2. Conroy MJ, Peterson JT. 2009. Integrating management, research, and monitoring: balancing the 3-legged stool. Pages 2-10 in Cederbaum SB, Faircloth BC, Terhune TM, Thompson JJ, Carroll JP, editors. Gamebird 2006: Quail VI and Perdix XII. 31 May-4 June 2006. Athens, Georgia: Warnell School of Forestry and Natural Resources.

Found at DOI: http://dx/doi.org/10.3996/052013-JFWM035.S3; also available at http://people.oregonstate. edu/ peterjam/ConroyandPeterson2009.pdf (324 KB PDF)

Reference S3. Cowardin LM, Shaffer TL, Arnold PM. 1995. Evaluations of duck habitat and estimation of duck population sizes with a remote-sensing-based system. Biological Science Report 2. Washington, D.C.: U.S. Fish and Wildlife Service. 
Found at DOI: http://dx/doi.org/10.3996/052013JFWM-035.S4; also available at http://www.npwrc.usgs. gov/resource/birds/duckhab/ (2,489 KB PDF)

Reference S4. Kushlan JA. 2002. Waterbird conservation for the Americas: North American waterbird conservation plan, version 1. Washington, D.C.: Waterbird Conservation for the Americas.

Found at DOI: http://dx/doi.org/10.3996/052013JFWM-035.S5; also available at http://www.waterbird conservation.org/pdfs/plan_files/complete.pdf (6,268 KB PDF)

Reference S5. [NRCS] Natural Resources Conservation Service. 1995. Soil survey geographic survey (SSURGO) database: data use information. Miscellaneous publication 1527. Fort Worth, Texas: National Cartography and GIS Center.

Found at DOI: http://dx/doi.org/10.3996/052013JFWM-035.S6; also available at ftp://ftp.igsb.uiowa.edu/ gis_library/Support_Data/Soils/SSURGO.PDF (339 KB PDF)

Reference S6. [PPJV] Prairie Pothole Joint Venture. 2005. Prairie Pothole Joint Venture implementation plan: introduction. Denver: U.S. Fish and Wildlife Service.

Found at DOI: http://dx/doi.org/10.3996/052013JFWM-035.S7; also available at http://www.ppjv.org/ implement2.htm (2,886 KB PDF)

Reference S7. Stubbs M. 2007. Land conversion in the Northern Plains. Washington, D.C.: Congressional Research Service, Library of Congress.

Found at DOI: http://dx/doi.org/10.3996/052013JFWM-035.S8; also available at http://new.nationalaglaw center.org/wp-content/uploads/assets/crs/RL33950.pdf (869 KB PDF)

Reference S8. [USDA] U.S. Department of Agriculture. 2007. Census of agriculture.

Found at DOI: http://dx/doi.org/10.3996/052013JFWM-035.S9; also available at http://www.agcensus. usda.gov/Publications/2007/Full_Report/ (6,611 KB PDF)

Reference S9. [USFWS] U.S. Fish and Wildlife Service and Canadian Wildlife Service. 1986. North American Waterfowl Management Plan: a strategy for cooperation. Washington, D.C.: U.S. Fish and Wildlife Service.

Found at DOI: http://dx/doi.org/10.3996/052013JFWM-035.S10; also available at http://www.fws.gov/ birdhabitat/nawmp/files/NAWMP.pdf (12.7 MB PDF)

Reference 510. [USFWS] U.S. Fish and Wildlife Service. 2008. Strategic habitat conservation handbook. Washington D.C.: Department of the Interior, U.S. Fish and Wildlife Service Division of Realty.

Found at DOI: http://dx/doi.org/10.3996/052013JFWM-035.S11; also available at http://www.fws.gov/ landscape-conservation/pdf/SHCHandbook.pdf $\quad(2,390$ KB PDF)

Reference S11. [USFWS] U.S. Fish and Wildlife Service. 2011. Annual report of lands under the control of the U.S. Fish and Wildlife Service. Washington D.C.: Department of the Interior, U.S. Fish and Wildlife Service Division of Realty.

Found at DOI: http://dx/doi.org/10.3996/052013JFWM-035.S12; also available at http://www.fws.gov/ refuges/realty/archives/pdf/2010_Annual_Report_of_Lands. pdf (2,688 KB PDF)

Reference S12. [USGAO] U.S. Government Accountability Office. 2007. Prairie Pothole Region: at the current pace of acquisitions the U.S. Fish and Wildlife Service is unlikely to achieve its habitat protection goals for migratory birds. GAO Report 07-1093.

Found at DOI: http://dx/doi.org/10.3996/052013JFWM-035.S13; also available at http://www.gao.gov/ assets/270/267291.pdf (6,542 KB PDF)

Reference S13. Zimpfer NL, Rhodes WE, Silverman ED, Zimmerman GS, Richkus KD. 2012. Trends in duck breeding populations, 1955-2012. Washington, D.C.: U.S. Department of the Interior.

Found at DOI: http://dx/doi.org/10.3996/052013JFWM-035.S14; also available at http://www.fws.gov/ migratorybirds/Newreportspublications/PopulationStatus/ Trends/2012_Trend_Report_final.pdf (2,317 KB PDF)

\section{Acknowledgments}

This project resulted from discussions with conservation workers from a wide range of agencies and organizations including the United States Fish and Wildlife Service, The North Dakota Game and Fish Department, and The South Dakota Department of Game, Fish, and Parks. The manuscript was improved by critical reviews provided by the Subject Editor, G. Soulliere, and an anonymous referee.

Any use of trade, product, or firm names is for descriptive purposes only and does not imply endorsement by the U.S. Government.

\section{References}

Bluemle JP. 1991. The face of North Dakota. Revised edition. Educational Series 21. Bismarck: North Dakota Geological Survey. Available: https://www.dmr.nd. gov/ndgs/Publication_List/education.asp (August 2013).

Bode M, Wilson KA, Brooks TM, Turner WR, Mittermeier RA, McBride MF, Underwood EC, Possingham, HP. 2008. Cost-effective global conservation spending is robust to taxonomic group. Proceedings of the National Academy of Sciences 105:6498-6501.

Carriazo F, Claassen R, Cooper J. 2009. Crop insurance, disaster payments, and incentives for land use change in agriculture: a preliminary assessment. American Agricultural Economics Association, Milwaukee, Wisconsin (see Supplemental Material, Reference S1, http://dx/doi.org/10.3996/052013-JFWM-035.S2); also available: http://ageconsearch.umn.edu/bitstream/ 49218/2/Carriazo_AAEA09_April27.pdf (August 2013).

Cirera X, Masset E. 2010. Income distribution trends and future food demand. Philosophical Transactions of the Royal Society B: Biological Sciences 365:2821-2834. 
Conroy MJ, Peterson JT. 2009. Integrating management, research, and monitoring: balancing the 3-legged stool. Pages 2-10 in Cederbaum SB, Faircloth BC, Terhune TM, Thompson JJ, Carroll JP, editors. Gamebird 2006: Quail VI and Perdix XII. 31 May-4 June 2006. Athens, Georgia: Warnell School of Forestry and Natural Resources (see Supplemental Material, Reference S2, http://dx/doi.org/10.3996/052013-JFWM-035. S3); also available: http://people.oregonstate.edu/ peterjam/ConroyandPeterson2009.pdf (August 2013).

Cowardin LM, Shaffer TL, Arnold PM. 1995. Evaluations of duck habitat and estimation of duck population sizes with a remote-sensing-based system. Biological Science Report 2. Washington, D.C.: U.S. Fish and Wildlife Service (see Supplemental Material, Reference S3, http://dx/doi.org/10.3996/052013-JFWM-035.S4); also available: http://www.npwrc.usgs.gov/resource/birds/ duckhab/ (August 2013).

Doherty KE, Ryba AJ, Stemler CL, Neimuth ND, Meeks WA. In press. Conservation planning in an era of change: state of the U.S. Prairie Pothole Region. Wildlife Society Bulletin. Available: http://onlinelibrary. wiley.com/doi/10.1002/wsb.284/full (August 2013).

Fisher JR, Dills B. 2012. Do private conservation activities match science-based conservation priorities? PloS ONE 7: e46429.

Greenwood RJ, Sargeant AB, Johnson DH, Cowardin LM, Shaffer TL. 1995. Factors associated with duck nest success in the prairie pothole region of Canada. Wildlife Monographs 128.

Horn DJ, Phillips ML, Koford RR, Clark WR, Sovada MA, Greenwood RJ. 2005. Landscape composition, patch size, and distance to edges: interactions affecting duck reproductive success. Ecological Applications 15: 1367-1376.

Johnson RR, Granfors DA, Niemuth ND, Estey ME, Reynolds RR. 2010. Delineating grassland bird conservation areas in the US Prairie Pothole Region. Journal of Fish and Wildlife Management 1:38-42.

Johnson DH, Haseltine SD, Cowardin LM. 1994. Wildlife habitat management on the northern prairie landscape. Landscape and Urban Planning 28:5-21.

Knight AT, Cowling RM, Rouget, M, Balmford, A, Lombard, AT, Campbell, BM. 2008. Knowing but not doing: selecting priority conservation areas and the research/implementation gap. Conservation Biology 22:610-617.

Kushlan JA. 2002. Waterbird conservation for the Americas: North American waterbird conservation plan, version 1. Washington, D.C.: Waterbird Conservation for the Americas (see Supplemental Material, Reference S4, http://dx/doi.org/10.3996/052013-JFWM-035.S5); also available: http://www.waterbirdconservation.org/ pdfs/plan_files/complete.pdf (August 2013).

Millett B, Johnson WC, Guntenspergen G. 2009. Climate trends of the North American prairie pothole region 1906-2000. Climatic Change 93:243-267.
[NRCS] Natural Resources Conservation Service. 1995. Soil survey geographic survey (SSURGO) database: data use information. Miscellaneous publication 1527. Fort Worth, Texas: National Cartography and GIS Center (see Supplemental Material, Reference S5, http://dx/ doi.org/10.3996/052013-JFWM-035.S6); also available: ftp://ftp.igsb.uiowa.edu/gis_library/Support_Data/Soils/ SSURGO.PDF (August 2013).

Newburn D, Reed S, Berck P, Merenlender A. 2005. Economics and land use change in prioritizing private land conservation. Conservation Biology 19:1411-1420.

[PPJV] Prairie Pothole Joint Venture. 2005. Prairie Pothole Joint Venture implementation plan: introduction. Denver: U.S. Fish and Wildlife Service (see Supplemental Material, Reference S6, http://dx/doi.org/10.3996/ 052013-JFWM-035.S7); also available: http://www. ppjv.org/implement2.htm (August 2013).

Polasky S. 2008. Why conservation planning needs socioeconomic data. Proceedings of the National Academy of Sciences 105:6505-6506.

Pressey RL, Cabeza M, Watts ME, Cowling RM, Wilson KA. 2007. Conservation planning in a changing world. Trends in Ecology and Evolution 22:583-592.

R Development Core Team. 2012. R: a language and environment for statistical computing. Version 2.15.1. Vienna: R Development Core Team. Available: http:// www.R-project.org (August 2013).

Ramankutty N, Foley JA, Olejniczak NJ. 2008. Land use and soil resources. Pages 23-40 in Braimoh AK, Vlek PLG, editors. Land-use change and global food production. New York: Springer Verlag.

Rashford BS, Walker JA, Bastian CT. 2011. Economics of grassland conversion to cropland in the Prairie Pothole Region. Conservation Biology 25:276-284.

Reynolds RE, Shaffer TL, Loesch CR, Cox RR Jr. 2006. The Farm Bill and duck production in the Prairie Pothole Region: increasing the benefits. Wildlife Society Bulletin 34:963-974.

Reynolds RE, Shaffer TL, Renner RW, Newton WE, Batt BDJ. 2001. Impact of the Conservation Reserve Program on duck recruitment in the US Prairie Pothole Region. Journal of Wildlife Management 65:765-780.

Rissman, AR, Lozier L, Comendant T, Kareiva P, Kiesecker JM, Rebecca M, Merenlender AM. 2007. Conservation easements: biodiversity protection and private use. Conservation Biology 21:709-718.

Searchinger T, Heimlich R, Houghton RA, Dong F, Elobeid A, Fabiosa J, Tokgoz S, Hayes D, Yu TH. 2008. Use of US croplands for biofuels increases greenhouse gases through emissions from land-use change. Science 319: 1238-1240.

Skagen SK, Thompson G. 2001. Northern Plains/Prairie Potholes regional shorebird conservation plan. Washington, D.C.: U.S. Fish and Wildlife Service.

Sokal RR, Rohlf FJ. 1995. Biometry. 3rd edition. New York: WH Freeman.

Stephens SE, Rotella JJ, Lindberg MS, Taper ML, Ringelman JK. 2005. Duck nest survival in the Missouri 
Coteau of North Dakota: landscape effects at multiple spatial scales. Ecological Applications 15:2137-2149.

Stephens SE, Walker JA, Blunck DR, Jayaraman A, Naugle DE, Ringelman JK, Smith AJ. 2008. Predicting risk of habitat conversion in native temperate grasslands. Conservation Biology 22:1320-1330.

Stubbs M. 2007. Land conversion in the Northern Plains. Washington, D.C.: Congressional Research Service, Library of Congress (see Supplemental Material, Reference S7, http://dx/doi.org/10.3996/052013-JFWM-035. S8); also available: http://new.nationalaglawcenter.org/ wp-content/uploads/assets/crs/RL33950.pdf (August 2013).

[USDA] U.S. Department of Agriculture. 2007. Census of agriculture. (see Supplemental Material, Reference S8, http://dx/doi.org/10.3996/052013-JFWM-035.S9; also available: http://www.agcensus.usda.gov/Publications/ 2007/Full_Report/ (August 2013).

[USDA] U.S. Department of Agriculture, National Agricultural Statistics Service. 2012. Quick Stats 2.0. Available: http://quickstats.nass.usda.gov/ (August 2013).

[USFWS] U.S. Fish and Wildlife Service. 1992. U.S. Fish and Wildlife Service Region 6 administrative and enforcement guidelines for perpetual grassland easements: Small Wetlands Acquisition Program. Revised February 1997. Lakewood, Colorado: U.S. Fish and Wildlife Service. (Living FWS document available by request from FWS Region 6 Easement Coordinator).

[USFWS] U.S. Fish and Wildlife Service. 2008. Strategic habitat conservation handbook. Washington, D.C.: Department of the Interior, U.S. Fish and Wildlife Service Division of Realty (see Supplemental Material, Reference S10, http:// dx/doi.org/10.3996/052013-JFWM-035.S11); also available: http://www.fws.gov/landscape-conservation/pdf/ SHCHandbook.pdf (August 2013).

[USFWS] U.S. Fish and Wildlife Service. 2011. Annual report of lands under the control of the U.S. Fish and Wildlife Service. Washington, D.C.: Department of the Interior, U.S. Fish and Wildlife Service Division of Realty (see Supplemental Material, Reference S11, http://dx/ doi.org/10.3996/052013-JFWM-035.S12); also available: http://www.fws.gov/refuges/realty/archives/pdf/ 2010_Annual_Report_of_Lands.pdf (August 2013).

[USFWS] U.S. Fish and Wildlife Service and Canadian Wildlife Service. 1986. North American Waterfowl Management Plan: a strategy for cooperation. Washington, D.C.: U.S. Fish and Wildlife Service (see Supplemental Material, Reference S9, http://dx/doi. org/10.3996/052013-JFWM-035.S10); also available: http://www.fws.gov/birdhabitat/nawmp/files/NAWMP. pdf (August 2013).

[USGAO] U.S. Government Accountability Office. 2007. Prairie Pothole Region: at the current pace of acquisitions the US Fish and Wildlife Service is unlikely to achieve its habitat protection goals for migratory birds. GAO Report 07-1093. (see Supplemental Material, Reference S12, http://dx/doi.org/10.3996/052013JFWM-035.S13), also available: http://www.gao.gov/ assets/270/267291.pdf (August 2013).

Walker J. 2011. Survival of duck nests, distribution of duck broods, and habitat conservation targeting in the Prairie Pothole Region. Doctoral dissertation. Fairbanks: University of Alaska Fairbanks.

Wickham H. 2009. ggplot2: elegant graphics for data analysis. New York: Springer.

Wright CK, Wimberly MC. 2013. Recent land use change in the Western Corn Belt threatens grasslands and wetlands. Proceedings of the National Academy of Sciences 110: 4134-4139.

Zimpfer NL, Rhodes WE, Silverman ED, Zimmerman GS, Richkus KD. 2012. Trends in duck breeding populations, 1955-2012. Washington, D.C.: U.S. Department of the Interior (see Supplemental Material, Reference S13, http://dx/doi.org/10.3996/052013-JFWM-035.S14), also available: http://www.fws.gov/migratorybirds/ Newreportspublications/PopulationStatus/Trends/2012 Trend_Report_final.pdf (August 2013). 